\title{
A breakthrough biosorbent in removing heavy metals: Equilibrium, kinetic, thermodynamic and mechanism analyses in a lab-scale study
}

Atefeh Abdolali ${ }^{\mathrm{a}}$, Huu Hao $\mathrm{Ngo}^{\mathrm{a},{ }^{*},}$, Wenshan Guo ${ }^{\mathrm{a}}$, Shaoyong Lu ${ }^{\mathrm{b}}$, Shiao-Shing Chen ${ }^{\mathrm{c}}$, Nguyen Cong Nguyen $^{\mathrm{c}}$, Xinbo Zhang ${ }^{\mathrm{d}}$, Jie Wang ${ }^{\mathrm{e}}$, Yun $\mathrm{Wu}^{\mathrm{e}}$

\footnotetext{
${ }^{a}$ Centre for Technology inWater and Wastewater, School of Civil and Environmental Engineering, University of Technology Sydney, Broadway, NSW 2007, Australia

${ }^{\mathrm{b}}$ Chinese Research Academy of Environmental Science, Beijing 100012, China

${ }^{\mathrm{c}}$ Institute of Environmental Engineering and Management, National Taipei University of Technology, No. 1, Sec. 3, Chung-Hsiao E. Rd, Taipei 106, Taiwan

${ }^{\mathrm{d}}$ Department of Environmental and Municipal Engineering, Tianjin Key Laboratory of Aquatic Science and Technology, Tianjin Chengjian University, Jinjing Road 26, Tianjin 300384, China

${ }^{\mathrm{e}}$ School of Environmental and Chemical Engineering, Tianjin Polytechnic University, Tianjin 300387, China

* Corresponding author at: School of Civil and Environmental Engineering, University of Technology, Sydney (UTS), PO Box 123, Broadway, NSW2007, Australia.

E-mail address: h.ngo@uts.edu.au (H.H. Ngo).
}

\section{Highlights}

- A novel multi-metal binding biosorbent (MMBB) was studied.

- The biosorption of $\mathrm{Cd}^{2+}, \mathrm{Cu}^{2+}, \mathrm{Pb}^{2+}$ and $\mathrm{Zn}^{2+}$ on MMBB was evaluated.

- Hydroxyl, carbonyl and amine groups are involved in metal binding of MMBB.

- Equilibrium data were presented and the best fitting models were identified.

- The obtained results recommend this MMBB as potentially low-cost biosorbent.

\begin{abstract}
A breakthrough biosorbent namely multi-metal binding biosorbent (MMBB) made from a combination of tea wastes, maple leaves and mandarin peels, was prepared to evaluate their biosorptive potential for removal of $\mathrm{Cd}(\mathrm{II}), \mathrm{Cu}(\mathrm{II}), \mathrm{Pb}$ (II) and $\mathrm{Zn}$ (II) from multi-metal aqueous solutions. FTIR and SEM were conducted, before and after biosorption, to explore the intensity and position of the available functional groups and changes in adsorbent surface morphology. Carboxylic, hydroxyl and amine groups were found to be the principal functional groups for the sorption of metals. MMBB exhibited best performance at $\mathrm{pH} 5.5$ with maximum sorption capacities of $31.73,41.06,76.25$ and $26.63 \mathrm{mg} / \mathrm{g}$ for $\mathrm{Cd}(\mathrm{II}), \mathrm{Cu}(\mathrm{II})$, $\mathrm{Pb}$ (II) and $\mathrm{Zn}(\mathrm{II})$, respectively. Pseudo-first and pseudo-second-order models represented the kinetic experimental data in different initial metal concentrations very well. Among two-
\end{abstract}


parameter adsorption isotherm models, the Langmuir equation gave a better fit of the equilibrium data. For $\mathrm{Cu}(\mathrm{II})$ and $\mathrm{Zn}$ (II), the Khan isotherm describes better biosorption conditions while for $\mathrm{Cd}(\mathrm{II})$ and $\mathrm{Pb}(\mathrm{II})$, the Sips model was found to provide the best correlation of the biosorption equilibrium data. The calculated thermodynamic parameters indicated feasible, spontaneous and exothermic biosorption process. Overall, this novel MMBB can effectively be utilized as an adsorbent to remove heavy metal ions from aqueous solutions.

Keywords: Heavy metal; Biosorption; Isotherm; Kinetic; Thermodynamics; Lignocellulosic waste

\section{Introduction}

Heavy metals are discharged to aquatic environments from various industries such as paper, textile, plastic, ceramic and cement manufacturing, mining and electronics plating. These poorly biodegradable pollutants are harmful for all plants, animals and human life due to high environmental mobility in soil and water and also a strong tendency for bioaccumulation in the living tissues along the food chain (Vargas-García et al., 2012, Akar et al., 2012 and Bulut and Tez, 2007). In order to remediate polluted water and wastewater streams, a wide range of treatment technologies are employed in industry (e.g. chemical precipitation, extraction, ion exchange, filtration, reverse osmosis, membrane bioreactor and electrochemical techniques) (Santos et al., 2015,Abdolali et al., 2014a, Montazer-Rahmati et al., 2011 and $\mathrm{Fu}$ and Wang, 2011). Nonetheless, these methods are not effective enough in low concentrations and might be very expensive as a result of high chemical reagent and energy requirements, as well as the disposal problem of toxic secondary sludge (Bulut and Tez, 2007 and Sud et al., 2008).

Therefore, introducing a properly eco-friendly and cost effective technology for wastewater treatment has provoked many researchers into this matter in recent decades (Abdolali et al., 2014b, Tang et al., 2013, Fu et al., 2013, Kumar et al., 2012, Hossain et al., 2012, WitekKrowiak et al., 2011, Gadd, 2009, Volesky, 2007 and Šćiban et al., 2007) to use cheap agroindustrial wastes and by-products as biosorbents. Some of these materials include sawdust and wood waste (Wahab et al., 2010, Bulut and Tez, 2007 and Šćiban et al., 2007), sugarcane bagasse (Homagai et al., 2010, Martín-Lara et al., 2010 and Khoramzadeh et al., 2013),fruit rind, pulp and seeds (Martín-Lara et al., 2010; Liu et al., 2012, Pehlivan et al., 2012 and Schiewer and Patil, 2008), wheat or barley straw, rice husk, hull and straw (Asadi et al., 2008), and olive pomace and stone (Blázquez et al., 2010, Blázquez et al., 2009 and Fiol et al., 2006).

All of the previous attempts have been made to study the agro-industrial wastes and byproducts individually. The novelty of the present work is using combination of selected agroindustrial multi-metal binding biosorbents for removal of cadmium, copper, lead and zinc ions from synthetic aqueous multi-metal solutions. The significant difference between previous studies and current work is gaining the advantages and also using the biosorptive 
potentials of various biosorbents in a combination. The purpose of blending different lignocellulosic materials is having all potentials of biosorbents for heavy metal uptake (Abdolali et al., 2014a, Martín-Lara et al., 2010 and Martín-Lara et al., 2010). Also these wastes were selected because of the good results reported in other literatures for heavy metal removal (Abdolali et al., 2014a, Feng et al., 2011 and Amarasinghe and Williams, 2007). Additionally, they are properly available in Australia and also all over the world.

Firstly, the adsorption studies were carried out to select the best combination of different biosorbents, as mentioned hereinabove. Then the experiments were continued to compare the effect of different contact times, $\mathrm{pH}$, initial metal concentration, temperature, and biosorbent dose and particle size on biosorptive potential of selected combination. The results were mainly evaluated by two popular kinetic models of pseudo-first-order and pseudo-secondorder correlations and three two-parameter and three three-parameter adsorption models (Langmuir, Freundlich, Dubinin-Radushkevich, Khan, Sips and Redlich-Peterson). In addition, thermodynamic parameters were determined for the sorption of all metal ions to explain the process feasibility.

\section{Material and methods}

\subsection{Preparation of adsorbents and heavy metal-containing effluent}

The stock solutions containing $\mathrm{Cd}, \mathrm{Cu}, \mathrm{Pb}$ and $\mathrm{Zn}$ were prepared by dissolving cadmium, copper, lead and zinc nitrate salt, $\mathrm{Cd}\left(\mathrm{NO}_{3}\right)_{2} \cdot 4 \mathrm{H}_{2} \mathrm{O}, \mathrm{Cu}_{3}(\mathrm{NO})_{2} \cdot 3 \mathrm{H}_{2} \mathrm{O}, \mathrm{Pb}\left(\mathrm{NO}_{3}\right)_{2}$ and $\mathrm{Zn}\left(\mathrm{NO}_{3}\right)_{2} \cdot 6 \mathrm{H}_{2} \mathrm{O}$ in Milli-Q water. All the reagents used for analysis were of analytical reagent grade from Scharlau (Spain) and Chem-Supply Pty Ltd. (Australia). The metal concentration was analyzed by Microwave Plasma-Atomic Emission Spectrometer, MP-AES, (Agilent Technologies, USA).

The biosorbents were applied in metal removal process for selecting the best ones in term of biosorption capacity sawdust (SD), sugarcane (SC), corncob (CC), tea waste (TW), apple peel (AP), grape stalk (GS), palm tree skin (PS), eucalyptus leaves (EU), mandarin peel (MP), maple leaves (ML) and garden grass (GG). All biosorbents were collected from Sydney area or local markets. After using or removing their useable parts, they were washed by tap and distilled water to remove any dirt, color or impurity and then dried in the oven (Labec Laboratory Equipment Pty Ltd., Australia) at $105^{\circ} \mathrm{C}$ overnight. Having ground and sieved (RETSCH AS-200, Germany) to different sizes (< $75 \mu \mathrm{m}, 75-150 \mu \mathrm{m}, 150-300 \mu \mathrm{m}$ and $>300 \mu \mathrm{m})$, the natural biosorbents were kept in a desiccator prior to use in future experiments.

\subsection{Biosorption studies in batch system}

The tests were performed with synthetic multi-metal stock solution with concentration of $3000 \mathrm{mg} / \mathrm{L}$ for each metal, prepared by dilution in Milli-Q water. Solution $\mathrm{pH}$ was adjusted with $1 \mathrm{M} \mathrm{HCl}$ and $\mathrm{NaOH}$ solutions. 
A known weight of adsorbent $(5 \mathrm{~g} / \mathrm{L})$ was added to a series of $200 \mathrm{~mL}$ Erlenmeyer flasks containing $50 \mathrm{~mL}$ of metal solution on a shaker (Ratek, Australia) at room temperature and the flasks were shaken at $150 \mathrm{rpm}$ for $3 \mathrm{~h}$. After equilibration, to separate the biomasses from solutions, the solutions were filtered by Whatman ${ }^{\mathrm{TM}}$ GF/C-47 mm/circle (GE Healthcare, Buckinghamshire, UK) filter paper and final concentration of metal was measured using MPAES. All the experiments were carried out in duplicates. The statistical analysis was performed by analysis of variance (ANOVA).

The amount of heavy metal ion adsorbed, q (mg/g) was calculated from the following Eq.(1):

$$
q=\frac{v\left(C_{i}-C_{f}\right)}{m}
$$

where, $C_{i}$ and $C_{f}(\mathrm{mg} / \mathrm{L})$ are the initial and equilibrium metal concentrations in the solution, respectively. $v(\mathrm{~L})$ the solution volume and $m(\mathrm{~g})$ is the mass of biosorbent.

\subsection{Characterization of adsorbents by FTIR and SEM}

To determine the functional groups involved in biosorption of $\mathrm{Cd}(\mathrm{II}), \mathrm{Cu}(\mathrm{II}), \mathrm{Pb}$ (II) and $\mathrm{Zn}$ (II) onto MMBB, a comparison between the Fourier Transform Infrared Spectroscopy (FTIR) before and after meal loading was done using Shimadzu FTIR 8400S (Kyoto, Japan). Metal-loaded biosorbent were filtered and dried in the oven. The small amount of samples was placed in the FTIR chamber on the $\mathrm{KBr}$ plates for analyzing the functional groups involving in biosorbent process by comparing with unused multi-metal biosorbent.

Scanning Electron Microscopy (SEM) of the free and loaded MMBB was performed on ZEISS EVO|LS15 (Germany) at an accelerating voltage of $10 \mathrm{kV}$ and with the working distance of $10 \mu \mathrm{m}$ for MMBB to observe the porous properties of the biosorbents.

\subsection{Influence of $\mathrm{pH}$}

In order to study the effect of $\mathrm{pH}$ on heavy metal adsorption, the initial $\mathrm{pH}$ of the solutions varied from 2 to 5.5, by adding appropriate amounts of $\mathrm{NaOH}$ or $\mathrm{HCl}$ solutions. The batch procedure at each $\mathrm{pH}$ was followed as above described using an initial concentration of $50 \mathrm{mg} / \mathrm{L}$.

\subsection{Influence of contact time}

The contact time varied from 15 min to $5 \mathrm{~h}$ for the biosorption of $\mathrm{Cd}(\mathrm{II}), \mathrm{Cu}$ (II), $\mathrm{Pb}$ (II) and $\mathrm{Zn}$ (II) adsorption on $\mathrm{MMBB}$ at different initial concentrations of $50 \mathrm{mg} / \mathrm{L}$ and room temperature with similar procedures explained above.

\subsection{Influence of adsorbent dose}


The dependence of $\mathrm{Cd}(\mathrm{II}), \mathrm{Cu}(\mathrm{II}), \mathrm{Pb}(\mathrm{II})$ and $\mathrm{Zn}$ (II) adsorption on biosorbent dose was studied at room temperature and optimum $\mathrm{pH}$ by varying biosorbent doses $(0.2,1,2,5,10$ and $20 \mathrm{~g} / \mathrm{L})$.

\subsection{Influence of particle size}

In order to study the effect of particle size on adsorption, batch experiments as above described were carried out using the biosorbent with different particle sizes of $<75 \mu \mathrm{m}, 75$ $150 \mu \mathrm{m}, 150-300 \mu \mathrm{m}$ and $>300 \mu \mathrm{m}$ and an initial metal concentration of $50 \mathrm{mg} / \mathrm{L}$, at room temperature.

\subsection{Influence of temperature}

The effect of temperature on the $\mathrm{Cd}, \mathrm{Cu}, \mathrm{Pb}$, and $\mathrm{Zn}$ adsorption was investigated in the range $298-323 \mathrm{~K}\left(25-50{ }^{\circ} \mathrm{C}\right)$ in batch experiments already described and initial concentration of $1-$ $50 \mathrm{mg} / \mathrm{L}$.

\section{Results and discussion}

\subsection{Selection of adsorbents}

Eleven different natural biosorbents, namely sawdust, sugarcane, corncob, tea waste, apple peel, grape stalk, palm tree skin, eucalyptus leaves, mandarin peel, maple leaves and garden grass, individually were compared in regard to the biosorption capacities for $\mathrm{Cd}(\mathrm{II}), \mathrm{Cu}(\mathrm{II})$, $\mathrm{Pb}$ (II) and $\mathrm{Zn}$ (II) uptake in Fig. 1. The results indicate TW, ML and MP showed satisfying biosorptive capacity for all heavy metal ions (cadmium, copper, lead and zinc). SD and CC had quite less biosorptive potential in comparison with GG and GS and PS.AP, SC and EU results for $\mathrm{Pb}, \mathrm{Zn}, \mathrm{Cd}$ and $\mathrm{Cu}$ were very unsatisfactory that this type of waste will not be considered for study in combination with other biosorbents. TW:ML:MP combination was selected to apply for further batch experiments. 


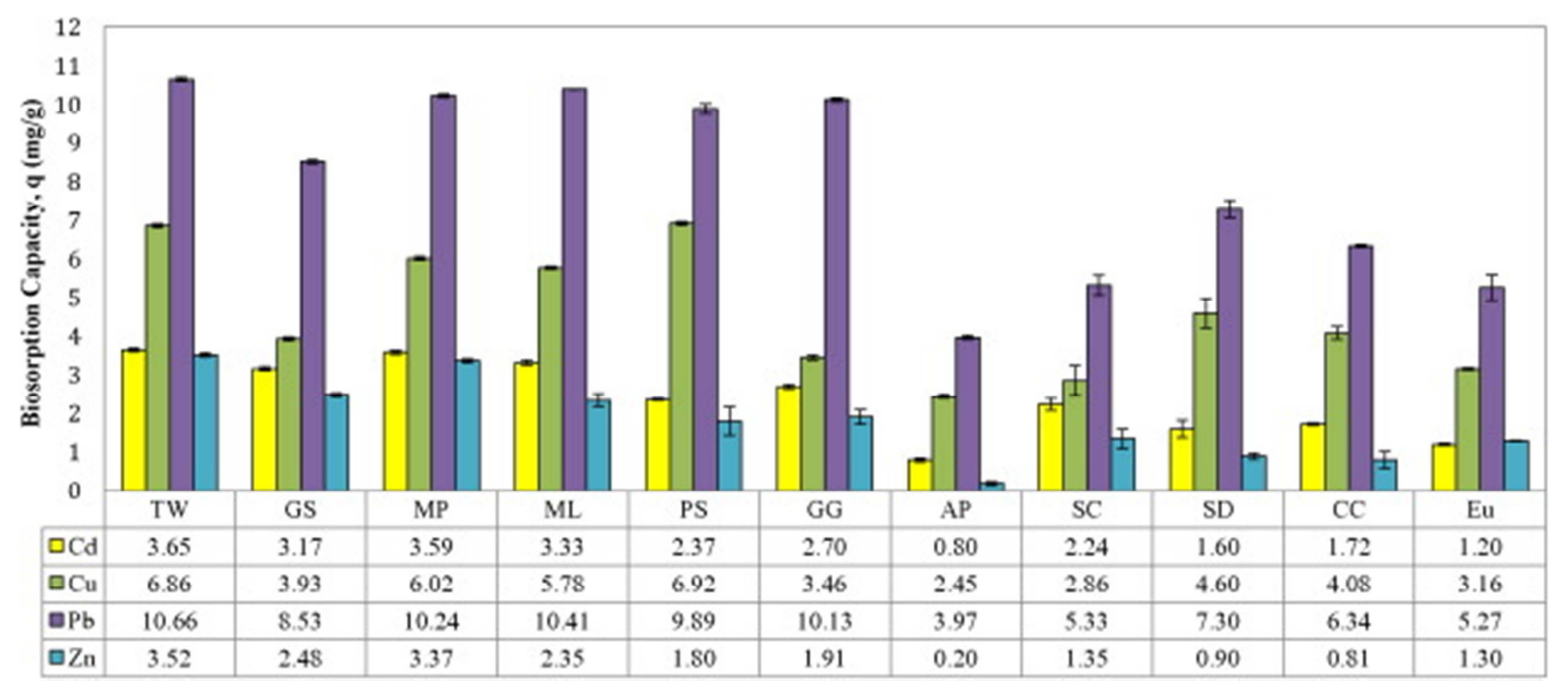

Fig. 1. Biosorption capacity of different agro-industrial wastes and by-products.

The effect of proportions for each biosorbent (TW:ML:MP) for heavy metal removal was carried out with the different ratios tabulated in the Fig. 2. All materials were separately weighed and mixed for removing any error and inaccuracy. To test the significance and adequacy of the model, statistical testing of the model in the form of analysis of variance (ANOVA) was done.

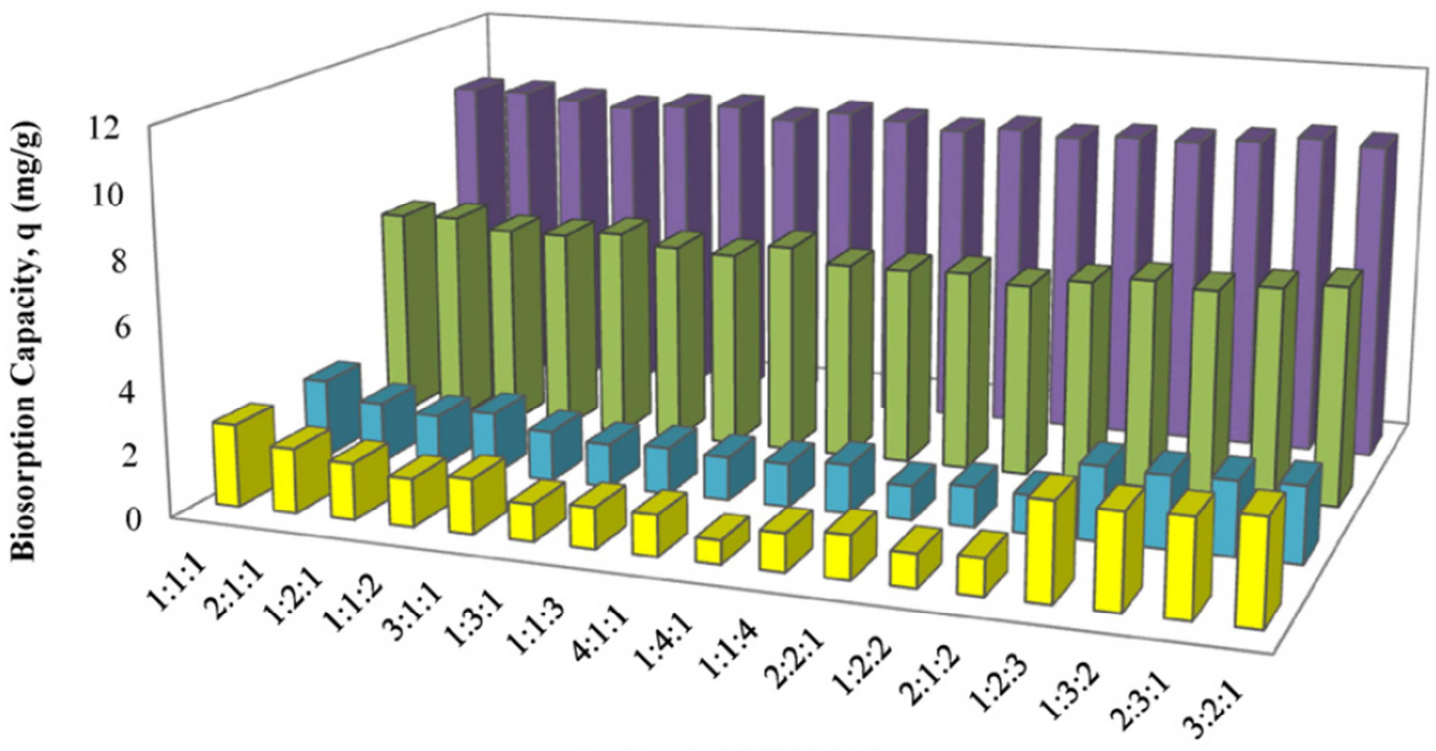

Ratio of TW:ML:MP

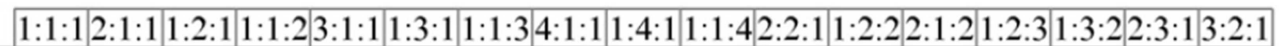
\begin{tabular}{|l|l|l|l|l|l|l|l|l|l|l|l|l|l|l|l|l|l|}
\hline$\square \mathrm{Cd}$ & 2.58 & 2.02 & 1.78 & 1.51 & 1.71 & 1.16 & 1.28 & 1.27 & 0.72 & 1.16 & 1.33 & 1.02 & 1.11 & 3.02 & 2.92 & 2.98 & 3.21 \\
\hline
\end{tabular} \begin{tabular}{|l|l|l|l|l|l|l|l|l|l|l|l|l|l|l|l|l|l|}
$\square \mathrm{Zn}$ & 2.46 & 1.90 & 1.68 & 1.96 & 1.56 & 1.35 & 1.44 & 1.35 & 1.35 & 1.53 & 1.09 & 1.27 & 1.22 & 2.33 & 2.26 & 2.31 & 2.38 \\
\hline
\end{tabular}

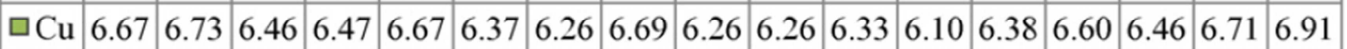

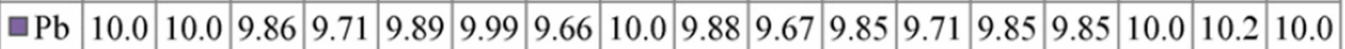


Fig. 2. Effect of ratio of tea waste: maple leaves: mandarin peel on $\mathrm{Cd}(\mathrm{II}), \mathrm{Cu}(\mathrm{II}), \mathrm{Pb}(\mathrm{II})$ and $\mathrm{Zn}$ (II) adsorption(initial $\mathrm{pH} 5.0-5.5 \pm 0.1$; room temperature, $22 \pm 1{ }^{\circ} \mathrm{C}$; contact time: $24 \mathrm{~h}$; initial metal conc.: $50 \mathrm{mg} / \mathrm{L}$; biosorbent dose: $5 \mathrm{~g} / \mathrm{L}$; rotary speed: $150 \mathrm{rpm}$ ).

Apparently, there are no significant differences between the equal proportions of 1:1:1 and the others, especially for lead and copper. This was despite the fact that ANOVA results for each metal indicated the rejection of the null hypothesis due to $\mathrm{P}$ value was less than 0.05 . The observed data are inconsistent with the assumption that the null hypothesis is true. Moreover, the ratio of 3:2:1 for TW:ML:MP showed the highest metal biosorption capacity. This is illustrated in Fig. 2 and will be referred as MMBB, hereinafter. The $\mathrm{pH}$, moisture content $(\%)$, loss of mass and bulk density $\left(\mathrm{g} / \mathrm{cm}^{3}\right)$ of MMBB were $4.97,18.86,0.93$ and 0.36 , respectively.

\subsection{Characterization of adsorbents by FTIR}

The FTIR spectrum of MMBB exhibited a large number of absorption peaks, indicating the complexity in nature of this adsorbent. It also confirmed changes in functional groups and surface properties of MMBB. The shift of some functional groups bands and their intensity significantly changed after heavy metal biosorption (Table 1).

These shifts may be attributed to carboxylic $(\mathrm{C}=\mathrm{O})$ and hydroxylic $(\mathrm{O}-\mathrm{H})$ groups on the MMBB's surface. They were dominantly active groups in $\mathrm{Cd}(\mathrm{II}), \mathrm{Cu}(\mathrm{II}), \mathrm{Pb}$ (II)and $\mathrm{Zn}(\mathrm{II})$ biosorption process, suggesting that acidic groups, carboxyl and hydroxyl, are main contributors in the complexation of metal cations and ion exchange processes. Amine and amide groups were found between medium intensity peaks in the frequency range of 16401560 with $132.13 \mathrm{~cm}^{-1}$ shift after biosorption process. The peaks detected in spectra were laid between 1320 and $1000 \mathrm{~cm}^{-1}$, which is related to $\mathrm{C}=\mathrm{O}$ stretch in amides, ketones, aldehydes, carboxylic acids and esters (Hossain et al., 2012 and Feng et al., 2011). A shift of $32.79 \mathrm{~cm}^{-1}$ was in the range of $1500-1450$, and is attributed to $\mathrm{C}=\mathrm{C}-\mathrm{C}$ asymmetric stretching aromatic rings. In addition, a big change $\left(78.12 \mathrm{~cm}^{-1}\right)$ occurred on the biosorbent after metal loading. This is reflected in the strong and broad band present between 3500 and $3200 \mathrm{~cm}^{-1}$. This may be assigned to complexation of metal ions with the ionized $\mathrm{O}-\mathrm{H}$ groups of polymeric compounds (i.e. alcohols, phenols and carboxylic acids) of cellulose and lignin of lignocellulosic materials (Hossain et al., 2012 and Feng et al., 2011). The changes of peaks in the range of $3000-2850 \mathrm{~cm}^{-1}$ and $3100-3000 \mathrm{~cm}^{-1}$ indicated the involvement of $\mathrm{H}-\mathrm{C}-\mathrm{H}$ asymmetric and symmetric stretch and $\mathrm{C}-\mathrm{H}$ stretch of aromatic rings, respectively, which can be found in the molecular structure of MMBB. The other detected peaks represent existence of $\mathrm{H}-\mathrm{C}=\mathrm{O}: \mathrm{C}-\mathrm{H}$ stretch in aldehydes in the range of $2850-2700 \mathrm{~cm}^{-1}$. 
Table 1. FTIR spectra and SEM images of (a) unloaded and (b) metal loaded-biosorbents.

\begin{tabular}{|c|c|c|c|c|c|}
\hline \multicolumn{2}{|c|}{ Frequency $\left(\mathrm{cm}^{-1}\right)$} & \multicolumn{2}{|c|}{ Transmittance $(\%)$} & \multirow{2}{*}{ Bond/functional group } & \multirow{2}{*}{ SEM images } \\
\hline & Loaded & Unloaded & Loaded & & \\
\hline 514.05 & 510.19 & 21.469 & 16.457 & C-Br stretch/Alkyl halides & \\
\hline 1005.92 & 1007.85 & 84.401 & 76.065 & $\begin{array}{l}\mathrm{C}=\mathrm{O} \text { stretch/alcohols, carboxylic acids, } \\
\text { esters and ethers }\end{array}$ & \\
\hline 1491.04 & 1458.25 & 83.572 & 74.933 & $\mathrm{C}-\mathrm{C}$ stretch (in-ring)/aromatics & \\
\hline 1590.38 & 1458.25 & 84.227 & 74.933 & $\mathrm{~N}-\mathrm{H}$ band $/ 1^{\circ}$ amines and amides & \\
\hline 1654.03 & 1654.03 & 78.747 & 72.344 & $-\mathrm{C}=\mathrm{C}-$ stretch/alkanes & \\
\hline 2721.68 & 2820.05 & 85.77 & 77.181 & $\mathrm{H}-\mathrm{C}=\mathrm{O}: \mathrm{C}-\mathrm{H}$ stretch/aldehydes & \\
\hline 2958.93 & 2957 & 83.061 & 75.485 & $\begin{array}{l}\mathrm{H}-\mathrm{C}-\mathrm{H} \text { asymmetric and symmetric } \\
\text { stretch/alkanes }\end{array}$ & \\
\hline 3096.85 & 3096.85 & 82.54 & 75.043 & $\mathrm{C}-\mathrm{H}$ stretch/aromatics & \\
\hline 3348.57 & 3230.91 & 81.419 & 74.193 & $-\mathrm{C} \equiv \mathrm{C}-\mathrm{H}: \mathrm{C}-\mathrm{H}$ stretch/alkynes & \\
\hline 3482.63 & 3404.51 & 81.609 & 74.247 & O-H stretch, H-bonded/alcohols and phenols & UTs \\
\hline
\end{tabular}




\subsection{SEM analysis}

From Table 1, SEM depicts the morphology changes of unloaded and loaded biosorbent. After biosorption of heavy metal ions, the surface became smoother with less porosity with probable metal entrapping and adsorbing on biosorbent. The SEM/EDS was reported in previous study (Abdolali et al., 2015).

\subsection{Effect of different physico-chemical parameters}

\subsubsection{Influence of $p H$}

Fig. 3(a) represents the effect of $\mathrm{pH}$ of the adsorption of cadmium, copper, lead and zinc altering in the range of 2.0-5.5.

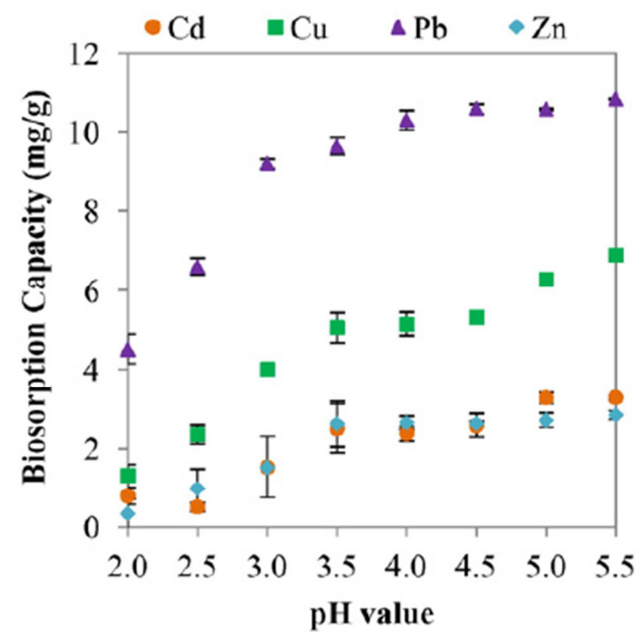

(a)

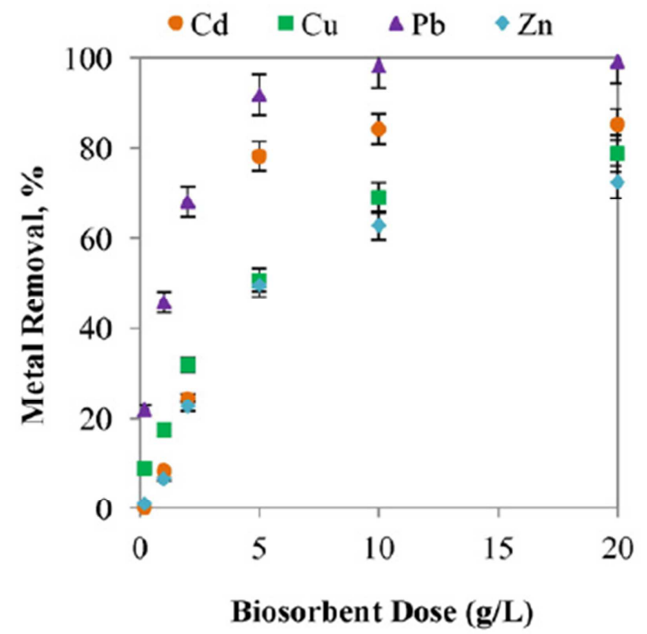

(c)

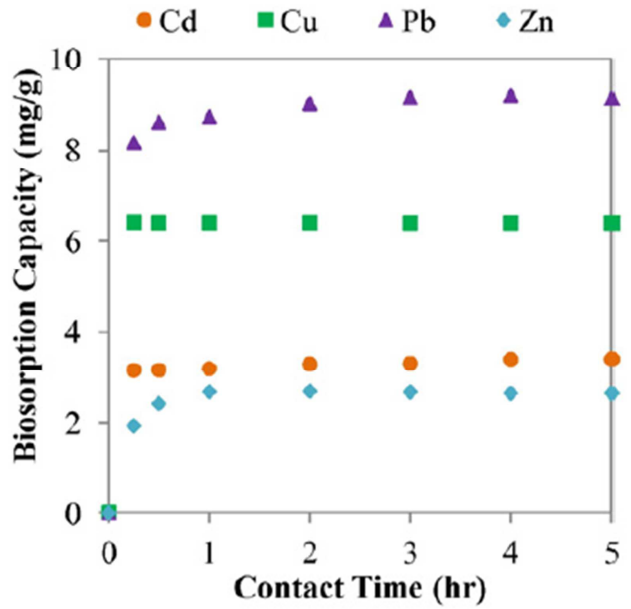

(b)

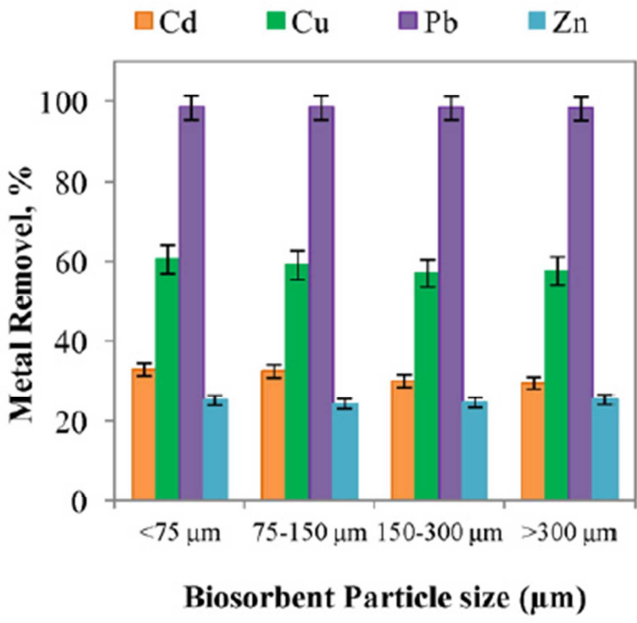

(d)

Fig. 3. Effect of (a) initial pH of solution, (b) contact time, (c) biosorbent dose and (d) biosorbent particle size on $\mathrm{Cd}(\mathrm{II}), \mathrm{Cu}(\mathrm{II}), \mathrm{Pb}(\mathrm{II})$ and $\mathrm{Zn}(\mathrm{II})$ adsorption (room temperature, $22 \pm 2{ }^{\circ} \mathrm{C}$; initial metal conc.: $\left.50 \mathrm{mg} / \mathrm{L}\right)$. 
The initial $\mathrm{pH}$ values above 5.5 are not preferable due to the observed presence of metal hydroxide precipitation, so as the experiments were not conducted beyond $\mathrm{pH}$ 5.5. Although all metal adsorption followed a similar pattern, the adsorption capacity of $\mathrm{Cu}$ and $\mathrm{Pb}$ increased significantly by an increase in $\mathrm{pH}$ values which are 1.30 to $6.90 \mathrm{mg} / \mathrm{g}$ and 4.51 to $10.84 \mathrm{mg} / \mathrm{g}$, respectively, while $\mathrm{Cd}$ and $\mathrm{Zn}$ uptake gradually increased up to 3.28 and $2.83 \mathrm{mg} / \mathrm{g}$ for $\mathrm{Cd}$ and $\mathrm{Zn}$, respectively. The results indicated that the optimum $\mathrm{pH}$ value was 5.5 for all metals.

\subsubsection{Influence of contact time}

It is evident from Fig. 3(b) that the rate of metal uptake was very fast within first 30 min as a result of the exuberant number of available active sites on adsorbent surfaces and then decreased until equilibrium was reached. Biosorption capacity leveled off at equilibrium state within $180 \mathrm{~min}$. Therefore, the biosorption time was set to $180 \mathrm{~min}$ in each experiment.

\subsubsection{Influence of adsorbent dose}

Biosorption capacity was also affected by biosorption dose and amount of available active sites and this effect is shown in Fig. 3(c). The experimental results indicate that the percentage removal of all metal ions on MMBB represents an equilibrium pattern for biosorbent amounts of $5 \mathrm{~g} / \mathrm{L}$ and more. Furthermore, the removal efficiency decreased by increasing initial metal ion solution with similar trends. The highest removal efficiencies changed in the range of $70 \%$, $84 \%, 98 \%$ and $61 \%$ for $\mathrm{Cd}, \mathrm{Cu}, \mathrm{Pb}$ and $\mathrm{Zn}$, with an initial concentration of $50 \mathrm{mg} / \mathrm{L}$, on $5 \mathrm{~g} / \mathrm{L}$ MMBB.

\subsubsection{Effect of biosorbent particle size}

The effect of particle size of biosorbent was conducted for $5 \mathrm{~g} / \mathrm{L}$ adsorbent dose and an initial concentration of $50 \mathrm{mg} / \mathrm{L}$. The results of different particle sizes of $<75 \mu \mathrm{m}, 75-150 \mu \mathrm{m}, 150$ $300 \mu \mathrm{m}$ and $>300 \mu \mathrm{m}$ are shown in Fig. 3(d). It was found that biosorption capacity did not significantly change by varying particle sizes. The reason was that these particle size

distributions were very small (less than $300 \mu \mathrm{m}$ ). The smaller biosorbent size exhibits better performance in regard with metal removal due to a higher surface area for metal adsorption; however the mechanical stability reduces particularly in column (Liu et al., 2012).

\subsection{Adsorption kinetics}

A kinetic investigation was carried out to quantify the adsorption rate controlling steps in $\mathrm{Cd}(\mathrm{II}), \mathrm{Cu}(\mathrm{II}), \mathrm{Pb}$ (II) and $\mathrm{Zn}$ (II) uptake on MMBB. The pseudo-first-order and pseudosecond-order kinetic models were applied for kinetic study (Febrianto et al., 2009).

The pseudo-first-order kinetic model known as the Lagergren equation and takes the form as: 


$$
q_{t}=q_{e}\left[1-\exp \left(-K_{1} t\right)\right]
$$

where, $q_{t}$ and $q_{e}$ are the metal adsorbed at time $t$ and equilibrium, respectively, and $K_{1}$ $\left(\mathrm{min}^{-1}\right)$ is the first-order reaction rate equilibrium constant.

The pseudo-second-order kinetic model considered in this study is given as:

$$
q_{t}=\frac{K_{2} q_{e}^{2} t}{1+K_{2} q_{e} t}
$$

where, $K_{2}\left(\mathrm{~g} \mathrm{mg}^{-1} \mathrm{~min}^{-1}\right)$ is the second-order reaction rate equilibrium constant.

The experimental data and obtained parameters of these models were measured by MATLAB ${ }^{\circledR}$ and summarized in Table 2. These kinetic models were exploited to describe the probable mechanism of biosorption. As shown in Table 2, with comparison between adsorption rate constants, the estimated $q e$ and the coefficients of correlation associated with the Lagergren pseudo-first-order and the pseudo-second-order kinetic models at room temperature for MMBB, it is obvious that both kinetic models well described all metal biosorption. However, the coefficients of correlation $\left(\mathrm{R}^{2}\right)$ of pseudo-second-order kinetic model were slightly larger than those of pseudo-first-order kinetic model for $\mathrm{Cu}$ in all initial concentrations. For lead and zinc ions, the Lagergren pseudo-first-order described equilibrium state and experimental data better than the other kinetic model. In addition, while pseudo-first-order kinetic model well fit the lower cadmium concentrations, pseudo-secondorder kinetic model outlined better description for higher $\mathrm{Cd}$ concentrations. Totally, the kinetic models indicated that chemical reaction would be presumably the rate limiting step of $\mathrm{Cd}, \mathrm{Cu}, \mathrm{Pb}$ and $\mathrm{Zn}$ biosorption on MMBB.

\subsection{Adsorption isotherm}

The correlation between the adsorbed and the aqueous metal concentrations at equilibrium has been described by the Langmuir, Freundlich, Dubinin-Radushkevich, Sips, RedlichPeterson and Khan adsorption isotherm models. All the model parameters which were evaluated by non-linear regression using MATLAB ${ }^{\circledR}$ software are presented in Table 3. Furthermore, residual root mean square error (RMSE), error sum of square (SSE) and correlation of determination $\left(\mathrm{R}^{2}\right)$ were used to measure the exactness of fitting.

The Langmuir equation describes the equilibrium condition better than the other models $\left(\mathrm{R}^{2}\right.$ : 0.99 and small RMSE values). The maximum amounts of biosorption capacity by monolayer adsorption assumption for $\mathrm{Cd}, \mathrm{Cu}, \mathrm{Pb}$ and $\mathrm{Zn}$ obtained from Langmuir equation are 31.73, $41.06,76.25$ and $26.63 \mathrm{mg} / \mathrm{g}$, respectively. Furthermore, it was understood that the Langmuir isotherm corresponded to a dominant ion exchange mechanism while the Freundlich isotherm showed adsorption-complexation reactions taking place at the outer heterogeneous surface of the adsorbent (Asadi et al., 2008 and Kazemipour et al., 2008). 
Among three-parameter isotherm models, for $\mathrm{Cu}(\mathrm{II})$ and $\mathrm{Zn}(\mathrm{II})$, Khan isotherm describes biosorption conditions moderately better than Sips and Redlich-Peterson models, while for $\mathrm{Cd}(\mathrm{II})$ and $\mathrm{Pb}$ (II), the Sips model was found to provide the best correlation of the biosorption equilibrium data. The foregoing analysis of isotherm models shows that the better fit for $\mathrm{Cd}(\mathrm{II}), \mathrm{Cu}(\mathrm{II}), \mathrm{Pb}(\mathrm{II})$ and $\mathrm{Zn}$ (II) biosorption is produced by three-parameter isotherm models rather than two-parameter isotherm models.

Table 2. Adsorption rate constants, the estimated $q_{e}$ and the coefficients of correlation associated with the Lagergren pseudo-first and pseudo-second order, kinetic models.

\begin{tabular}{|c|c|c|c|c|c|c|}
\hline \multirow[t]{2}{*}{ Metal } & \multirow[t]{2}{*}{ Kinetic models } & \multirow[t]{2}{*}{ Parameter } & \multicolumn{4}{|c|}{ Metal concentration } \\
\hline & & & $10 \mathrm{mg} / \mathrm{L}$ & $20 \mathrm{mg} / \mathrm{L}$ & $50 \mathrm{mg} / \mathrm{L}$ & $100 \mathrm{mg} / \mathrm{L}$ \\
\hline \multirow[t]{11}{*}{ Cd } & Experiment & $q e(\mathrm{mg} / \mathrm{g})$ & 1.63 & 2.92 & 3.30 & 5.40 \\
\hline & Pseudo-1st-order & $q e(\mathrm{mg} / \mathrm{g})$ & 1.62 & 2.92 & 3.36 & 5.29 \\
\hline & & $K_{1}\left(\mathrm{~h}^{-1}\right)$ & 12.66 & 8.55 & 10.70 & 10.57 \\
\hline & & $\mathrm{R}^{2}$ & 0.997 & 0.999 & 0.990 & 0.990 \\
\hline & & SSE & 0.005 & 0.001 & 0.104 & 0.245 \\
\hline & & RMSE & 0.019 & 0.008 & 0.089 & 0.137 \\
\hline & Pseudo-2nd-order & $q e(\mathrm{mg} / \mathrm{g})$ & 1.63 & 2.94 & 3.40 & 5.34 \\
\hline & & $K_{2}(\mathrm{mg} / \mathrm{gh})$ & 55.25 & 12.24 & 11.08 & 7.355 \\
\hline & & $\mathrm{R}^{2}$ & 0.998 & 0.997 & 0.995 & 0.995 \\
\hline & & SSE & 0.004 & 0.022 & 0.044 & 0.126 \\
\hline & & RMSE & 0.018 & 0.043 & 0.058 & 0.098 \\
\hline \multirow[t]{11}{*}{$\mathbf{C u}$} & Experiment & $q e(\mathrm{mg} / \mathrm{g})$ & 1.35 & 4.30 & 6.40 & 7.16 \\
\hline & Pseudo-1st-order & $q e(\mathrm{mg} / \mathrm{g})$ & 1.34 & 4.24 & 6.39 & 7.16 \\
\hline & & $\mathrm{K}_{1}\left(\mathrm{~h}^{-1}\right)$ & 8.50 & 11.73 & 8.047 & 9.02 \\
\hline & & $\mathrm{R}^{2}$ & 0.993 & 0.999 & 0.999 & 0.999 \\
\hline & & SSE & 0.011 & 0.009 & 0.005 & 0.174 \\
\hline & & RMSE & 0.029 & 0.027 & 0.006 & 0.115 \\
\hline & Pseudo-2nd-order & $q e(\mathrm{mg} / \mathrm{g})$ & 1.35 & 4.26 & 6.39 & 7.20 \\
\hline & & $K_{2}(\mathrm{mg} / \mathrm{gh})$ & 2.09 & 2.21 & 3.32 & 5.99 \\
\hline & & $\mathrm{R}^{2}$ & 0.996 & 0.998 & 0.999 & 0.996 \\
\hline & & SSE & 0.006 & 0.026 & 0.532 & 0.174 \\
\hline & & RMSE & 0.021 & 0.046 & 0.006 & 0.115 \\
\hline \multirow[t]{11}{*}{$\mathbf{P b}$} & Experiment & $q e(\mathrm{mg} / \mathrm{g})$ & 1.81 & 4.15 & 9.02 & 13.58 \\
\hline & Pseudo-1st-order & $q e(\mathrm{mg} / \mathrm{g})$ & 1.81 & 4.14 & 9.06 & 13.76 \\
\hline & & $K_{1}\left(\mathrm{~h}^{-1}\right)$ & 9.27 & 15.29 & 8.93 & 7.17 \\
\hline & & $\mathrm{R}^{2}$ & 0.985 & 0.999 & 0.995 & 0.999 \\
\hline & & SSE & 0.046 & 0.001 & 0.354 & 0.109 \\
\hline & & RMSE & 0.059 & 0.009 & 0.165 & 0.091 \\
\hline & Pseudo-2nd-order & $q e(\mathrm{mg} / \mathrm{g})$ & 1.80 & 4.15 & 8.99 & 13.57 \\
\hline & & $K_{2}(\mathrm{mg} / \mathrm{gh})$ & 1.22 & 0.79 & 0.72 & 1.21 \\
\hline & & $\mathrm{R}^{2}$ & 0.976 & 0.999 & 0.985 & 0.971 \\
\hline & & SSE & 0.073 & 0.021 & 1.149 & 5.081 \\
\hline & & RMSE & 0.074 & 0.013 & 0.297 & 0.625 \\
\hline \multirow[t]{11}{*}{ Zn } & Experiment & $q e(\mathrm{mg} / \mathrm{g})$ & 1.38 & 2.43 & 2.88 & 3.72 \\
\hline & Pseudo-1st-order & $q e(\mathrm{mg} / \mathrm{g})$ & 1.32 & 2.43 & 2.64 & 3.77 \\
\hline & & $K_{1}\left(\min ^{-1}\right)$ & 9.05 & 8.25 & 5.17 & 12.78 \\
\hline & & $\mathrm{R}^{2}$ & 0.989 & 0.999 & 0.998 & 0.996 \\
\hline & & SSE & 0.015 & 0.008 & 0.007 & 0.043 \\
\hline & & RMSE & 0.035 & 0.012 & 0.024 & 0.057 \\
\hline & Pseudo-2nd-order & $q e(\mathrm{mg} / \mathrm{g})$ & 1.32 & 2.45 & 2.68 & 3.79 \\
\hline & & $K_{2}(\mathrm{mg} / \mathrm{g} \min )$ & 0.75 & 0.23 & 0.08 & 0.30 \\
\hline & & $\mathrm{R}^{2}$ & 0.982 & 0.996 & 0.988 & 0.998 \\
\hline & & SSE & 0.028 & 0.021 & 0.076 & 0.023 \\
\hline & & RMSE & 0.046 & 0.042 & 0.76 & 0.42 \\
\hline
\end{tabular}


Table 3. Isotherm constants of two- and three-parameter models for $\mathrm{Cd}(\mathrm{II}), \mathrm{Cu}(\mathrm{II}), \mathrm{Pb}$ (II) and $\mathrm{Zn}$ (II) adsorption (initial metal conc.: $10-500 \mathrm{mg} / \mathrm{L}$ ).

\begin{tabular}{|c|c|c|c|c|c|}
\hline \multirow[t]{2}{*}{ Models } & & \multicolumn{4}{|l|}{ Metal } \\
\hline & & Cadmium & Copper & Lead & Zinc \\
\hline \multicolumn{6}{|l|}{$\begin{array}{l}\text { Two-parameter models } \\
\text { Langmuir }\end{array}$} \\
\hline \multicolumn{6}{|c|}{$q_{e}=\frac{q_{m, L} b_{L} C_{e}}{1+b_{L} C_{e}}$} \\
\hline & $q_{m, L}(\mathrm{mg} / \mathrm{g})$ & 31.73 & 41.06 & 76.25 & 26.63 \\
\hline & $b_{L}(\mathrm{~L} / \mathrm{mg})$ & 0.005 & 0.010 & 0.034 & 0.050 \\
\hline & SSE & 35.74 & 62.35 & 13.50 & 0.84 \\
\hline & $\mathrm{R}^{2}$ & 0.99 & 0.99 & 0.99 & 0.99 \\
\hline & RMSE & 3.45 & 4.56 & 2.12 & 0.53 \\
\hline \multirow[t]{6}{*}{ Freundlich } & $q_{e}=K_{F} C_{e}^{1 / t}$ & & & & \\
\hline & $K_{F}$ & 0.92 & 1.64 & 7.80 & 0.46 \\
\hline & $\mathrm{n}$ & 1.88 & 1.96 & 2.38 & 1.80 \\
\hline & SSE & 50.37 & 44.37 & 50.11 & 2.92 \\
\hline & $\mathrm{R}^{2}$ & 0.79 & 0.92 & 0.98 & 0.97 \\
\hline & RMSE & 4.09 & 3.84 & 4.08 & 0.98 \\
\hline \multirow[t]{6}{*}{ Dubinin-Radushkevich } & \multicolumn{5}{|c|}{$q_{e}=q_{D-R} \exp \left(-B_{D-R} \varepsilon_{D-R}^{2}\right)$} \\
\hline & $q_{D R}(\mathrm{mg} / \mathrm{g})$ & 22.78 & 32.17 & 56.32 & 12.19 \\
\hline & $B_{D R}$ & 0.075 & 0.042 & 0.016 & 0.067 \\
\hline & SSE & 13.94 & 32.99 & 33.5 & 7.81 \\
\hline & $\mathrm{R}^{2}$ & 0.96 & 0.94 & 0.87 & 0.92 \\
\hline & RMSE & 2.15 & 3.31 & 10.57 & 1.61 \\
\hline \multicolumn{6}{|l|}{ Three-parameter models } \\
\hline \multirow[t]{7}{*}{ Khan } & \multicolumn{5}{|c|}{$q_{e}=\frac{q_{m, K} b_{K} C_{e}}{\left(1+b_{K} C_{e}\right)^{a_{K}}}$} \\
\hline & $q_{m, K}(\mathrm{mg} / \mathrm{g})$ & 21.53 & 43.04 & 85.43 & 16.30 \\
\hline & & 0.013 & 0.23 & 0.09 & 0.68 \\
\hline & $b_{K}(\mathrm{~L} / \mathrm{mg})$ & 0.006 & 0.097 & 0.003 & 0.004 \\
\hline & SSE & 15.2 & 1.02 & 28.66 & 1.39 \\
\hline & $\mathrm{R}^{2}$ & 0.95 & 0.99 & 0.96 & 0.99 \\
\hline & RMSE & 2.74 & 0.71 & 3.78 & 0.83 \\
\hline \multirow[t]{7}{*}{ Redlich-Peterson } & \multicolumn{5}{|c|}{$q_{e}=\frac{K_{R P} C_{e}}{1+a_{R P} C_{\rho}^{\beta_{R P}}}$} \\
\hline & $\beta_{R P}$ & 0.21 & 3.03 & 0.81 & 0.44 \\
\hline & $K_{R P}(\mathrm{~L} / \mathrm{g})$ & 0.08 & 0.20 & 4.17 & 0.18 \\
\hline & $a_{R P}(\mathrm{~L} / \mathrm{mg})$ & 0.67 & 0.02 & 0.15 & 0.41 \\
\hline & SSE & 66.39 & 27.45 & 1.02 & 3.91 \\
\hline & $\mathrm{R}^{2}$ & 0.79 & 0.95 & 0.99 & 0.97 \\
\hline & RMSE & 5.76 & 3.70 & 0.71 & 1.21 \\
\hline \multirow[t]{8}{*}{ Sips } & \multirow{2}{*}{\multicolumn{5}{|c|}{$q_{e}=\frac{K_{S} C_{e}^{\beta_{S}}}{1+a_{S} C_{e}^{\beta_{S}}}$}} \\
\hline & & & & & \\
\hline & $\beta_{S}$ & 3.56 & 1.80 & 0.77 & 1.13 \\
\hline & $K_{S}(\mathrm{~L} / \mathrm{g})$ & 0.028 & 0.017 & 4.457 & 0.051 \\
\hline & $a_{S}(\mathrm{~L} / \mathrm{mg})$ & 1.29 & 5.14 & 0.05 & 0.02 \\
\hline & SSE & 7.59 & 15.01 & 0.43 & 1.45 \\
\hline & $\mathrm{R}^{2}$ & 0.97 & 0.97 & 0.99 & 0.98 \\
\hline & RMSE & 1.95 & 2.74 & 0.46 & 0.85 \\
\hline
\end{tabular}

Various kinds of agro-industrial wastes and by-products were studied for heavy metal removal. A comparison between maximum adsorptive capacities of MMBB and some other 
adsorbents is shown in Table 4. These study results are compatible with other adsorbents by higher or at least equal sorption potential for heavy metal removal from aqueous solutions. Furthermore, combination of several types of low-cost agro-industrial waste might provide more selectivity as a result of increase in different effective functional groups involved in metal binding. Hence, this kind of adsorbent will be recommended for its significant advantages.

Table 4. Biosorption capacities of various adsorbents.

\begin{tabular}{|c|c|c|c|}
\hline Adsorbent & Adsorbate & $q_{\max }(\mathrm{mg} / \mathrm{g})$ & Reference \\
\hline \multirow[t]{4}{*}{ ММВВ } & $\mathrm{Cd}(\mathrm{II})$ & 31.73 & Present study \\
\hline & $\mathrm{Cu}(\mathrm{II})$ & 41.06 & \\
\hline & $\mathrm{Pb}(\mathrm{II})$ & 76.25 & \\
\hline & $\mathrm{Zn}(\mathrm{II})$ & 26.63 & \\
\hline Cashew nut shell & $\mathrm{Zn}(\mathrm{II})$ & 24.98 & Kumar et al. (2012) \\
\hline Rice straw & $\mathrm{Cd}(\mathrm{II})$ & 13.89 & Ding et al. (2012) \\
\hline Sugarcane bagasse & $\mathrm{Cd}(\mathrm{II})$ & 69.06 & Garg et al. (2008) \\
\hline \multirow[t]{3}{*}{ Sawdust } & $\mathrm{Cu}(\mathrm{II})$ & 6.88 & Šćiban et al. (2007) \\
\hline & $\mathrm{Zn}(\mathrm{II})$ & 0.96 & \\
\hline & $\mathrm{Cd}(\mathrm{II})$ & 0.15 & \\
\hline \multirow[t]{4}{*}{ Olive stone } & $\mathrm{Pb}(\mathrm{II})$ & 92.6 & Fiol et al. (2006) \\
\hline & $\mathrm{Cd}(\mathrm{II})$ & 77.3 & \\
\hline & $\mathrm{Ni}(\mathrm{II})$ & 21.3 & \\
\hline & $\mathrm{Cu}(\mathrm{II})$ & 20.2 & \\
\hline \multirow[t]{3}{*}{ Orange peel } & $\mathrm{Pb}(\mathrm{II})$ & 113.5 & Feng et al. (2011) \\
\hline & $\mathrm{Cd}(\mathrm{II})$ & 63.35 & \\
\hline & $\mathrm{Ni}(\mathrm{II})$ & 9.82 & \\
\hline \multirow[t]{2}{*}{ Tea waste } & $\mathrm{Cu}(\mathrm{II})$ & 48 & Amarasinghe and Williams (2007) \\
\hline & $\mathrm{Pb}(\mathrm{II})$ & 65 & \\
\hline
\end{tabular}

\subsection{Biosorption mechanism}

The main mechanisms known for metal sorption on lignocellulosic biosorbents are chelating, ion exchanging and making complexion with functional groups and releasing $\left[\mathrm{H}_{3} \mathrm{O}\right]^{+}$into aqueous solution. Ionic exchange is known as a mechanism which involves electrostatic interaction between positive metallic cations and the negatively charged groups in the cell walls. The ion exchange reaction could be represented as (Fiol et al., 2006):

$$
\equiv \mathrm{S}-\mathrm{M}_{2 / \mathrm{n}}(\mathrm{s})+\mathrm{Me}^{2+}(\mathrm{aq}) \Leftrightarrow \equiv \mathrm{S}-\mathrm{M}(\mathrm{s})+\frac{2}{\mathrm{n}} \mathrm{M}^{2+}(\mathrm{aq})
$$

where $\mathrm{M}^{+}$represents $\mathrm{K}^{+}, \mathrm{Mg}^{2+}$ or $\mathrm{Ca}^{2+}$ and $\mathrm{Me}^{2+}$ is heavy metal ions like $\mathrm{Pb}^{2+}, \mathrm{Cd}^{2+}, \mathrm{Ni}^{2+}$, and $\mathrm{Cu}^{2+}$. On the other hand, many characterization studies confirmed that ion exchange mechanism was included in heavy metal biosorption process rather than complexation with functional groups on the biosorbent surface and also showed the role of sodium, potassium, calcium and magnesium present in the adsorbent in ion exchange mechanism (Ding et al., 2012 and Akar et al., 2012). 
The amount of adsorbed heavy metal ions and released alkali ions $\left(\mathrm{Na}^{+}, \mathrm{K}^{+}, \mathrm{Mg}^{2+}\right.$ and $\left.\mathrm{Ca}^{2+}\right)$ concentration $(\mathrm{mg} / \mathrm{L})$ is shown in Fig. 4. Apparently, metal adsorption on biosorbent surface made $\mathrm{Na}^{+}, \mathrm{K}^{+}, \mathrm{Mg}^{2+}$ and $\mathrm{Ca}^{2+}$ ions release in aqueous medium. It confirmed the possibility of ion-exchange mechanism in biosorption process by comparing total amount of adsorbed heavy metal ions $(1.43 \mathrm{mmol} / \mathrm{L})$ and released alkali ions $(1.51 \mathrm{mmol} / \mathrm{L})$ which were approximately equal.

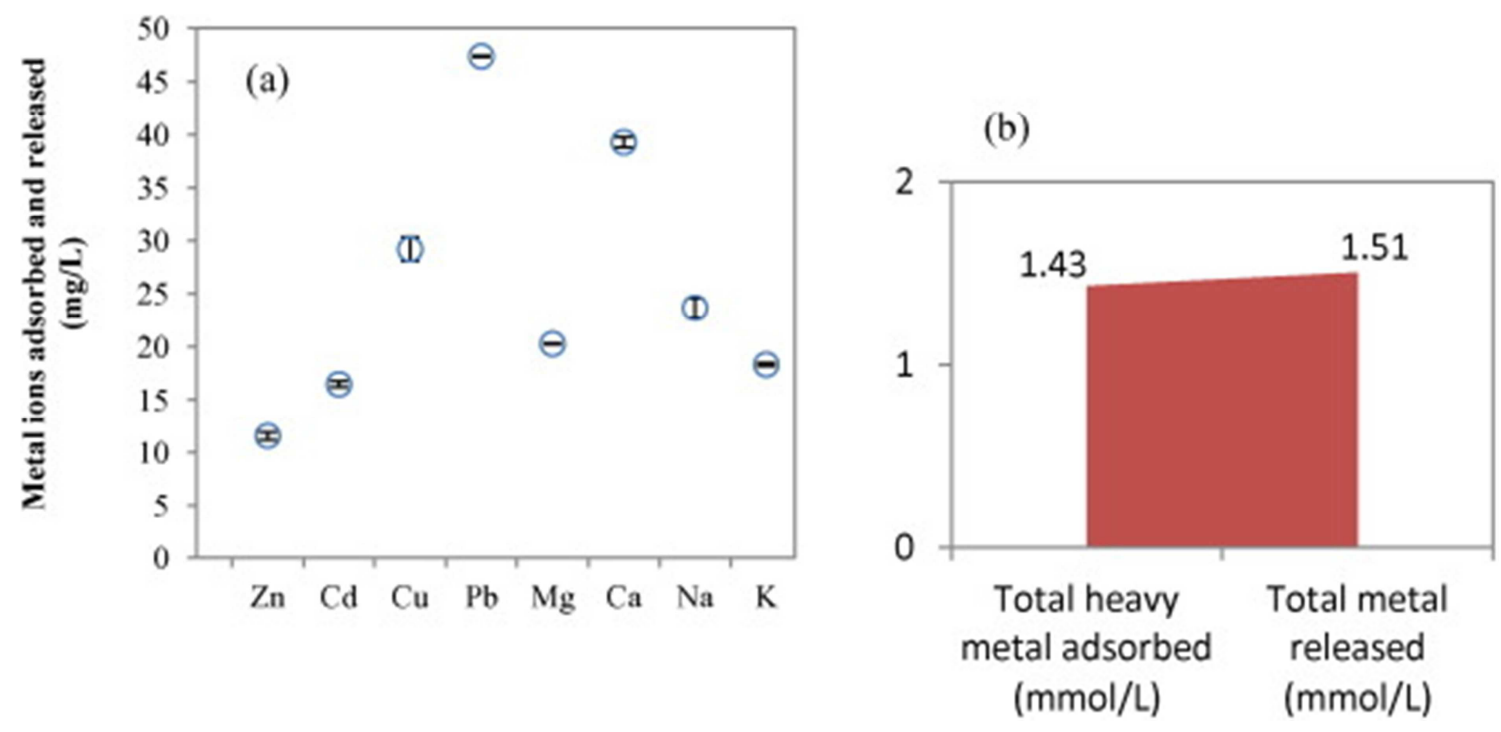

Fig. 4. Comparison of (a) individual and (b) total metal ions adsorbed and released in biosorption process (initial heavy metal conc.: $50 \mathrm{mg} / \mathrm{L}$ ).

In a previous study on this MMBB (Abdolali et al., 2015), SEM/EDS analysis confirmed that the variance in intensity of $\mathrm{K}, \mathrm{Na}$ and $\mathrm{Ca}$ peaks might be due to ion-exchange mechanism of metal uptake.

In addition, the mean free energy of adsorption $E=\frac{1}{\sqrt{2 B_{D-R}}}$ calculated from DubininRadushkevich isotherm can evaluate sorption properties and main mechanism. Based on hypothesis of Dubinin-Radushkevich isotherm, it is concluded that $E$ values between 8 and $12 \mathrm{~kJ} / \mathrm{mol}$ mean chemical adsorption whereas $E$ values less than $8 \mathrm{~kJ} / \mathrm{mol}$ means physical adsorption or ion exchange process at the cell surface. Hence, according to calculated $B D$ $R$ for $\mathrm{Cd}, \mathrm{Cu}, \mathrm{Pb}$ and $\mathrm{Zn}, E$ values show physical adsorption or ion exchange for four metal removal process whose calculated values are $2.58,3.45,5.59$ and $2.73 \mathrm{~kJ} / \mathrm{mol}$ for $\mathrm{Cd}, \mathrm{Cu}, \mathrm{Pb}$ and $\mathrm{Zn}$ respectively which are all less than $8 \mathrm{~kJ} / \mathrm{mol}$.

With respect to kinetic modeling, it also established that metal uptake by the micro-organisms takes place in two consecutive stages: a passive and quick uptake that follows by an active and very slow uptake. The first step is regarded to be physical adsorption or ion exchange (Witek-Krowiak, 2012) which was well represented by pseudo-second-order kinetic model. 


\subsection{Adsorption thermodynamics}

The biosorptive potential of MMBB for $\mathrm{Cd}(\mathrm{II}), \mathrm{Cu}(\mathrm{II}), \mathrm{Pb}$ (II) and $\mathrm{Zn}$ (II) removal was studied at the temperatures of $25,30,40$ and $50{ }^{\circ} \mathrm{C}$.

Table 5. Thermodynamic parameters, $\Delta \mathrm{G}^{\circ}(\mathrm{kJ} / \mathrm{mol}), \Delta \mathrm{H}^{\circ}(\mathrm{kJ} / \mathrm{mol})$ and $\Delta \mathrm{S}^{\circ}(\mathrm{kJ} / \mathrm{mol} \mathrm{K})$, for adsorption of $\mathrm{Cd}(\mathrm{II}), \mathrm{Cu}(\mathrm{II}), \mathrm{Pb}(\mathrm{II})$ and $\mathrm{Zn}(\mathrm{II})$ adsorption.

\begin{tabular}{|c|c|c|c|c|c|c|}
\hline Metal & $T(\mathbf{K})$ & $q_{m, L}(\mathrm{mg} / \mathrm{g})$ & $k_{c}=q_{e} / C_{e}$ & $\Delta \mathbf{G}^{\circ}$ & $\Delta \mathbf{H}^{\circ}$ & $\Delta \mathbf{S}^{\circ}$ \\
\hline \multirow[t]{4}{*}{ Cd } & 298 & 2.93 & 1.14 & -17.44 & -4.11 & 0.87 \\
\hline & 303 & 3.15 & 1.07 & -17.57 & & \\
\hline & 313 & 3.18 & 1.00 & -17.98 & & \\
\hline & 323 & 3.40 & 0.90 & -18.27 & & \\
\hline \multirow[t]{4}{*}{$\mathrm{Cu}$} & 298 & 10.00 & 0.59 & -15.81 & -15.45 & 2.75 \\
\hline & 303 & 7.48 & 0.58 & -16.03 & & \\
\hline & 313 & 11.08 & 0.55 & -16.42 & & \\
\hline & 323 & 10.11 & 1.3 & -19.25 & & \\
\hline \multirow[t]{4}{*}{$\mathbf{P b}$} & 298 & 10.47 & 8.29 & -22.35 & -11.93 & 0.90 \\
\hline & 303 & 7.74 & 6.91 & -22.27 & & \\
\hline & 313 & 12.63 & 6.89 & -23.00 & & \\
\hline & 323 & 11.35 & 10.43 & -24.85 & & \\
\hline \multirow[t]{4}{*}{ Zn } & 298 & 3.75 & 0.23 & -13.47 & -3.64 & -0.54 \\
\hline & 303 & 3.76 & 0.23 & -13.70 & & \\
\hline & 313 & 3.61 & 0.22 & -14.04 & & \\
\hline & 323 & 4.05 & 0.2 & -14.23 & & \\
\hline Metal & $T(\mathbf{K})$ & $q_{m, L}(\mathrm{mg} / \mathrm{g})$ & $k_{c}=1 / b_{L}$ & $\Delta \mathbf{G}^{\circ}$ & $\Delta \mathbf{H}^{\circ}$ & $\Delta \mathbf{S}^{\circ}$ \\
\hline \multirow{4}{*}{ Cd } & 298 & 2.93 & 2.97 & -19.81 & -10.06 & 0.61 \\
\hline & 303 & 3.15 & 3.24 & -20.36 & & \\
\hline & 313 & 3.18 & 3.28 & -21.07 & & \\
\hline & 323 & 3.40 & 3.56 & -21.96 & & \\
\hline \multirow[t]{4}{*}{$\mathrm{Cu}$} & 298 & 10.00 & 14.29 & -23.70 & -18.30 & 2.58 \\
\hline & 303 & 7.48 & 17.01 & -24.54 & & \\
\hline & 313 & 11.08 & 30.77 & -26.89 & & \\
\hline & 323 & 10.11 & 25.51 & -27.25 & & \\
\hline \multirow[t]{4}{*}{$\mathbf{P b}$} & 298 & 10.47 & 1.13 & -17.41 & -12.65 & 1.65 \\
\hline & 303 & 7.74 & 1.12 & -17.70 & & \\
\hline & 313 & 12.63 & 2.48 & -20.34 & & \\
\hline & 323 & 11.35 & 1.42 & -19.50 & & \\
\hline \multirow[t]{4}{*}{$\mathbf{Z n}$} & 298 & 3.75 & 5.32 & -21.26 & -17.72 & 2.62 \\
\hline & 303 & 3.76 & 13.00 & -23.86 & & \\
\hline & 313 & 3.61 & 11.72 & -24.38 & & \\
\hline & 323 & 4.05 & 13.23 & -25.48 & & \\
\hline Metal & $T(\mathbf{K})$ & $q_{m, L}(\mathrm{mg} / \mathrm{g})$ & $\boldsymbol{k}_{c}=\boldsymbol{K}_{F}^{n}$ & $\Delta \mathbf{G}^{\circ}$ & $\Delta \mathbf{H}^{\circ}$ & $\Delta \mathbf{S}^{\circ}$ \\
\hline \multirow[t]{4}{*}{ Cd } & 298 & 2.93 & 1.01 & -17.13 & -6.95 & 0.02 \\
\hline & 303 & 3.15 & 0.98 & -17.34 & & \\
\hline & 313 & 3.18 & 0.98 & -17.92 & & \\
\hline & 323 & 3.40 & 1.01 & -18.57 & & \\
\hline \multirow[t]{4}{*}{$\mathrm{Cu}$} & 298 & 10.00 & 0.37 & -14.66 & -16.58 & 3.20 \\
\hline & 303 & 7.48 & 0.45 & -15.40 & & \\
\hline & 313 & 11.08 & 0.37 & -15.42 & & \\
\hline & 323 & 10.11 & 1.00 & -18.55 & & \\
\hline \multirow[t]{4}{*}{$\mathbf{P b}$} & 298 & 10.47 & 14.35 & -23.71 & -12.68 & 0.92 \\
\hline & 303 & 7.74 & 14.92 & -24.21 & & \\
\hline & 313 & 12.63 & 18.25 & -25.53 & & \\
\hline & 323 & 11.35 & 17.65 & -26.26 & & \\
\hline \multirow[t]{4}{*}{$\mathbf{Z n}$} & 298 & 3.75 & 0.33 & -14.38 & -2.57 & -0.91 \\
\hline & 303 & 3.76 & 0.22 & -13.55 & & \\
\hline & 313 & 3.61 & 0.23 & -14.13 & & \\
\hline & 323 & 4.05 & 0.24 & -14.68 & & \\
\hline
\end{tabular}


The experimental results indicated dependency of adsorption on the temperature and are listed in Table 5. The thermodynamic parameters for the adsorption process such as free energy change $\left(\Delta \mathrm{G}^{\circ}\right)$, enthalpy change $\left(\Delta \mathrm{H}^{\circ}\right)$, and entropy change $\left(\Delta \mathrm{G}^{\circ}\right)$ were calculated to evaluate thermodynamic feasibility of the sorption process and to confirm its nature. The Gibbs free energy indicates the degree of spontaneity of sorption process, and the higher negative value reflects a more energetically favorable sorption. $\Delta \mathrm{H}^{\circ}$ and $\Delta \mathrm{S}^{\circ}$ were obtained from the slop and intercept of the Van't Hoff plots (Fig. 5). The negative values of $\left(\Delta \mathrm{G}^{\circ}\right)$ for all metal ions indicate the spontaneous nature of metal biosorption on MMBB. The negative value of $\Delta \mathrm{H}^{\circ}$ showed that the sorption process was exothermic in nature.

Except for zinc, calculated $\Delta \mathrm{S}^{\circ}$ values for cadmium, copper and lead were positive, reflecting the increased randomness at the solid/solution interface during sorption. It also indicates an affinity of the sorbent towards $\mathrm{Cd}, \mathrm{Cu}$ and $\mathrm{Pb}$ ions. In addition, the low value of $\Delta \mathrm{S}^{\circ}$ may imply that no remarkable change in entropy occurred during the sorption of $\mathrm{Cd}, \mathrm{Cu}, \mathrm{Pb}$ and $\mathrm{Zn}$ ions on MMBB.
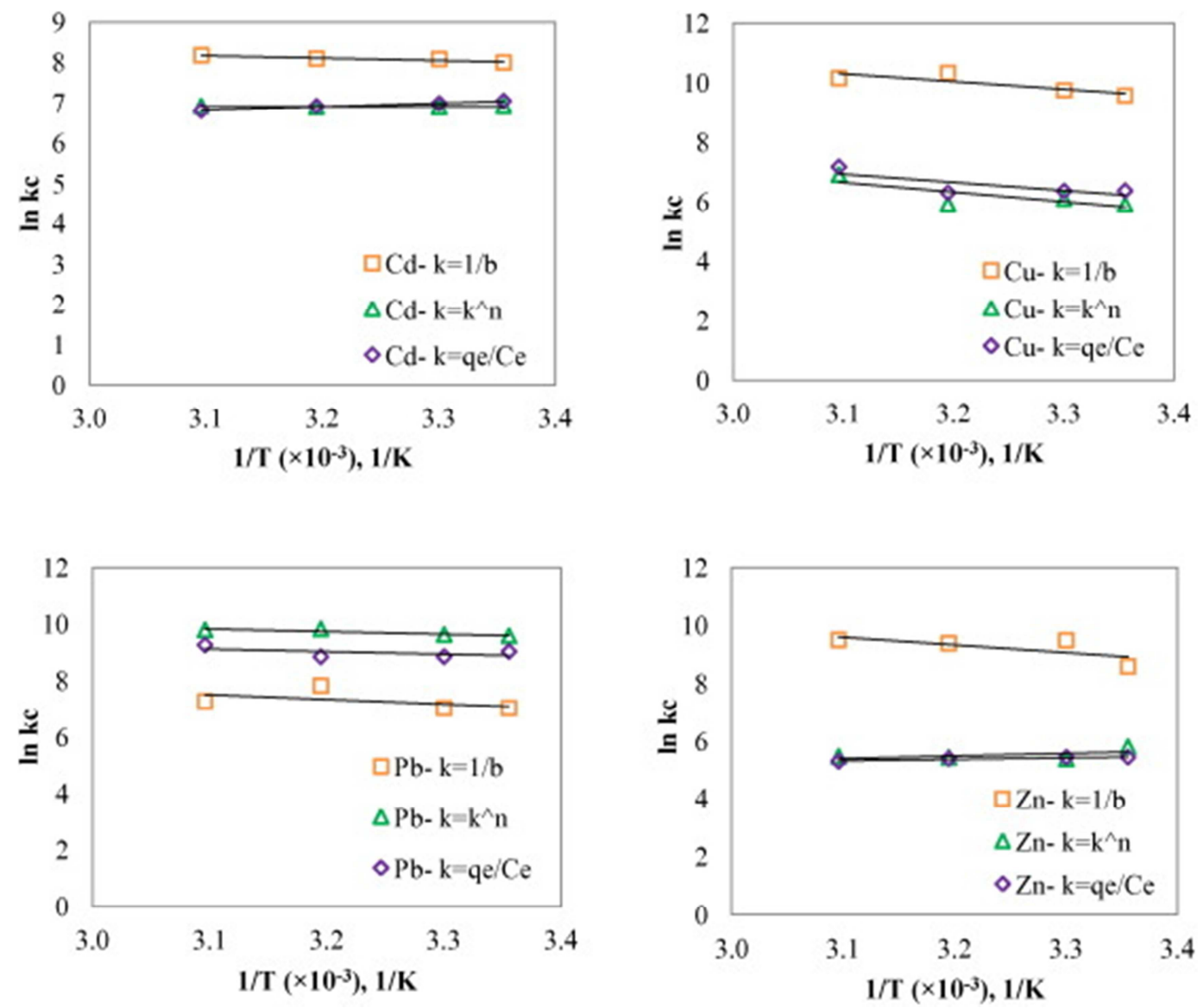

Fig. 5. Van't Hoff plots for $\mathrm{Cd}(\mathrm{II}), \mathrm{Cu}(\mathrm{II}), \mathrm{Pb}(\mathrm{II})$ and $\mathrm{Zn}$ (II) adsorption(initial pH $5.5 \pm 0.1$; initial metal conc.: $1-50 \mathrm{mg} / \mathrm{L}$; contact time: $3 \mathrm{~h}$; biosorbent dose: $5 \mathrm{~g} / \mathrm{L}$ ). 


\section{Conclusions}

The present work explores a new economical and selective lignocellulosic biosorbent containing tea waste, maple leaves and mandarin peels as an alternative to costly adsorbents for the removal of $\mathrm{Cd}(\mathrm{II}), \mathrm{Cu}(\mathrm{II}), \mathrm{Pb}$ (II) and $\mathrm{Zn}$ (II) ions. The low cost, rapid attainment of phase equilibrium (within $3 \mathrm{~h}$ ) and high sorption capacity values may be cited among the main advantages. Adsorption kinetics follows a pseudo-second-order kinetic model and negative values of $\Delta \mathrm{H}^{\circ}$ and $\Delta \mathrm{G}^{\circ}$ prove the exothermic and spontaneous nature of the biosorption phenomenon. Hence, this novel $\mathrm{MMBB}$ can be a promising adsorbent to eliminate heavy metal ions from aqueous solutions.

\section{Acknowledgments}

This work was supported by the Centre for Technology in Water and Wastewater (CTWW), School of Civil and Environmental Engineering (CEE), University of Technology, Sydney (UTS) and Australian Postgraduate Award.

\section{References}

1. A. Abdolali, W.S. Guo, H.H. Ngo, S.S. Chen, N.C. Nguyen, K.L. Tung, Typical lignocellulosic wastes and by-products for biosorption process in water and wastewater treatment: a critical review, Bioresour. Technol., 160 (2014), pp. 57-66

2. A. Abdolali, H.H. Ngo, W.S. Guo, D.J. Lee, K.L. Tung, X.C. Wang, Development and evaluation of a new multi-metal binding biosorbent, Bioresour. Technol., 160 (2014), pp. 98-106

3. A. Abdolali, H.H. Ngo, W.S. Guo, J.L. Zhou, B. Du, Q. Wei, X.C. Wang, P.D. Nguyen, Characterization of a multi-metal binding biosorbent: chemical modification and desorption studies, Bioresour. Technol., 193 (2015), pp. 477-487

4. S.T. Akar, S. Arslan, T. Alp, D. Arslan, T. Akar, Biosorption potential of the waste biomaterial obtained from cucumis melo for the removal of $\mathrm{Pb}^{2+}$ ions from aqueous media: equilibrium, kinetic, thermodynamic and mechanism analysis, Chem. Eng. J., 185-6 (2012), pp. 82-90

5. B.M.W.P.K. Amarasinghe, R.A. Williams, Tea waste as a low cost adsorbent for the removal of $\mathrm{Cu}$ and $\mathrm{Pb}$ from wastewater, Chem. Eng. J., 132 (2007), pp. 299-309

6. F. Asadi, H. Shariatmadari, N. Mirghaffari, Modification of rice hull and sawdust sorptive characteristics for remove heavy metals from synthetic solutions and wastewater, J. Hazard. Mater., 154 (2008), pp. 451-458

7. G. Blázquez, F. Hernáinz, M. Calero, M.A. Martín-Lara, G. Tenorio, The effect of pH on the biosorption of $\mathrm{Cr}(\mathrm{III})$ and $\mathrm{Cr}(\mathrm{VI})$ with olive stone, Chem. Eng. J., 148 (2009), pp. 473-479 
8. G. Blázquez, M. Calero, F. Hernáinz, G. Tenorio, M.A. Martín-Lara, Equilibrium biosorption of lead(II) from aqueous solutions by solid waste from olive-oil production, Chem. Eng. J., 160 (2010), pp. 615-622

9. Y. Bulut, Z. Tez, Removal of heavy metals from aqueous solution by sawdust adsorption, J. Environ. Sci., 19 (2007), pp. 160-166

10. Y. Ding, D. Jing, H. Gong, L. Zhou, X. Yang, Biosorption of aquatic cadmium(II) by unmodified rice straw, Bioresour. Technol., 114 (2012), pp. 20-25

11. J. Febrianto, A.N. Kosasih, J. Sunarso, Y.H. Ju, N. Indraswati, S. Ismadji, Equilibrium and kinetic studies in adsorption of heavy metals using biosorbent: a summary of recent studies, J. Hazard. Mater., 162 (2009), pp. 616-645

12. N. Feng, X. Guo, S. Liang, Y. Zhu, J. Liu, Biosorption of heavy metals from aqueous solutions by chemically modified orange peel, J. Hazard. Mater., 185 (2011), pp. 49-54

13. N. Fiol, I. Villaescusa, M. Martínez, N. Miralles, J. Poch, J. Serarols, Sorption of Pb(II), $\mathrm{Ni}(\mathrm{II}), \mathrm{Cu}(\mathrm{II})$ and $\mathrm{Cd}(\mathrm{II})$ from aqueous solution by olive stone waste, Sep. Purif. Technol., 50 (2006), pp. 132-140

14. F. Fu, Q. Wang, Removal of heavy metal ions from wastewaters: a review, J. Environ. Manag., 92 (2011), pp. 407-418

15. H.Z. Fu, M.H. Wang, Y.S. Ho, Mapping of drinking water research: a bibliometric analysis of research output during 1992-2011, Sci. Total Environ., 443 (2013), pp. 757765

16. G.M. Gadd, Biosorption: critical review of scientific rationale, environmental importance and significance for pollution treatment, J. Chem. Technol. Biotechnol., 84 (2009), pp. $13-28$

17. U. Garg, M.P. Kaur, G.K. Jawa, D. Sud, V.K. Garg, Removal of cadmium(II) from aqueous solutions by adsorption on agricultural waste biomass, J. Hazard. Mater., 154 (2008), pp. 1149-1157

18. P.L. Homagai, K.N. Ghimire, K. Inoue, Adsorption behavior of heavy metals onto chemically modified sugarcane bagasse, Bioresour. Technol., 101 (2010), pp. 2067-2069

19. M.A. Hossain, H.H. Ngo, W.S. Guo, T. Setiadi, Adsorption and desorption of copper(II) ions onto garden grass, Bioresour. Technol., 121 (2012), pp. 386-395

20. M. Kazemipour, M. Ansari, S. Tajrobehkar, M. Majdzadeh, H.R. Kermani, Removal of lead, cadmium, zinc, and copper from industrial wastewater by carbon developed from walnut, hazelnut, almond, pistachio shell, and apricot stone, J. Hazard. Mater., 150 (2008), pp. 322-327

21. E. Khoramzadeh, B. Nasernejad, R. Halladj, Mercury biosorption from aqueous solutions by sugarcane bagasse, J. Taiwan Inst. Chem. Eng., 44 (2013), pp. 266-269

22. P.S. Kumar, S. Ramalingam, R.V. Abhinaya, S.D. Kirupha, T. Vidhyadevi, S. Sivanesan, Adsorption equilibrium, thermodynamics, kinetics, mechanism and process design of zinc(II) ions onto cashew nut shell, Can. J. Chem. Eng., 90 (2012), pp. 973-982

A. Liu, H.H. Ngo, W.S. Guo, K.L. Tung, Optimal conditions for preparation of banana peels, sugarcane bagasse and watermelon rind in removing copper from water, Bioresour. Technol., 119 (2012), pp. 349-354 
23. M.Á. Martín-Lara, I.L.R. Rico, I.C.A. Vicente, G.B. García, M.C. de Hoces, Modification of the sorptive characteristics of sugarcane bagasse for removing lead from aqueous solutions, Desalination, 256 (2010), pp. 58-63

24. M.M. Montazer-Rahmati, P. Rabbani, A. Abdolali, A.R. Keshtkar, Kinetics and equilibrium studies on biosorption of cadmium, lead, and nickel ions from aqueous solutions by intact and chemically modified brown algae, J. Hazard. Mater., 185 (2011), pp. 401-407

25. E. Pehlivan, T. Altun, Ş. Parlayici, Modified barley straw as a potential biosorbent for removal of copper ions from aqueous solution, Food Chem., 135 (2012), pp. 2229-2234

26. S. Santos, G. Ungureanu, R. Boaventura, C. Botelho, Selenium contaminated waters: an overview of analytical methods, treatment options and recent advances in sorption methods, Sci. Total Environ., 521-2 (2015), pp. 246-260

27. S. Schiewer, S.B. Patil, Pectin-rich fruit wastes as biosorbents for heavy metal removal: equilibrium and kinetics, Bioresour. Technol., 99 (2008), pp. 1896-1903

28. M. Šćiban, B. Radetić, Ž. Kevrešan, M. Klašnja, Adsorption of heavy metals from electroplating wastewater by wood sawdust, Bioresour. Technol., 98 (2007), pp. 402-409

B. Sud, G. Mahajan, M.P. Kaur, Agricultural waste material as potential adsorbent for sequestering heavy metal ions from aqueous solutions -a review, Bioresour. Technol., 99 (2008), pp. 6017-6027

29. Y. Tang, L. Chen, X. Wei, Q. Yao, T. Li, Removal of lead ions from aqueous solution by the dried aquatic plant, Lemna perpusilla Torr, J. Hazard. Mater., 244-5 (2013), pp. 603612

30. M.C. Vargas-García, M.J. López, F. Suárez-Estrella, J. Moreno, Compost as a source of microbial isolates for the bioremediation of heavy metals: in vitro selection, Sci. Total Environ., 431 (2012), pp. 62-67

31. B. Volesky, Biosorption and me, Water Res., 41 (2007), pp. 4017-4029

32. M.A. Wahab, S. Jellali, N. Jedidi, Ammonium biosorption onto sawdust: FTIR analysis, kinetics and adsorption isotherms modelling, Bioresour. Technol., 101 (2010), pp. 50705075

33. A. Witek-Krowiak, Analysis of temperature-dependent biosorption of $\mathrm{Cu}^{2+}$ ions on sunflower hulls: kinetics, equilibrium and mechanism of the process, Chem. Eng. J., 192 (2012), pp. 13-20

34. A. Witek-Krowiak, R.G. Szafran, S. Modelski, Biosorption of heavy metals from aqueous solutions onto peanut shell as a low-cost biosorbent, Desalination, 265 (2011), pp. 126-134 